\title{
Boron content of wide soil groups of Siverek (Şanlıurfa) region
}

\author{
Mehmet Yalçın* \\ K. Mesut Çimrin ${ }^{1}$ \\ ${ }^{1}$ Mustafa Kemal University, Faculty of Agriculture, Soil Science and Plant Nutrition, Hatay, Turkey \\ * Corresponding author: myalcin@mku.edu.tr
}

\begin{abstract}
In the study, it was aimed to determine the boron content of the wide soil groups in Siverek county of Şanlıurfa province and to determine relations with some properties of the soil. For this purpose, a total of 76 soil samples were taken from two different depths $(0-20$ and 20-40 cm) and 38 points, representing the wide soil groups of Siverek county of Şanliurfa. Texture, $\mathrm{pH}$, salt, lime, organic matter and available boron contents of the soils were determined in the samples. The results of the research show that the $\mathrm{pH}$ contents of soils is between 6.91-7.98; salt content is between $0.02-0.13 \%$; clay content is between $24.32-67.76 \%$; sand content is between $2.40-62.96 \%$; silt content is between $6.00-68.72 \%$; lime content is between $0.38-14.55 \%$; organic matter content is between 1.11 $3.35 \%$ and boron content of them is between $0.01-1.99 \mathrm{mg} / \mathrm{kg}$. The obtainable boron content of the wide soil groups of Siverek county of Şanliurfa province was found to be $65.38 \%$ too little, $26.32 \%$ little, $7.90 \%$ adequate at the depth of $0-20 \mathrm{~cm}$, whereas it was found to be $81.58 \%$ too little, $15.79 \%$ little and $2.63 \%$ sufficient at 20 $40 \mathrm{~cm}$ depth. It was determined that there is a positive significant relationship between the obtainable boron content of soil and $\mathrm{pH}$ and lime contents. In addition, significant positive relationships between $\mathrm{pH}$ content and silt and lime were determined. Not only a negative significant relation between clay content and silt content of soils was determined, but negatively significant relations between sand content and silt and organic matter were determined, as well. At the same time, positive correlations were determined between the lime content of the soils and the organic matter.
\end{abstract}

Key words: Boron content, wide soil groups, soil properties

\section{INTRODUCTION}

Very few and limited levels of agricultural areas and agricultural inputs on earth increase the value of agricultural regions. The chemical, physical and biological properties of soils have an important place directly and indirectly on the amount of crops to be obtained from agricultural land. In order to obtain the best results from agricultural production, the well-known soil texture and characteristics is a very important factor affecting the agricultural production process (Karaduman and Çimrin 2016).

The desired level of plant nutrients in the soil is closely related to different environmental factors, including climatic conditions, together with soil factors such as $\mathrm{pH}$, salt, body, organic matter, lime and KDK (Özyazıc1 et al. 2013, Sevindik et al. 2017). It is known that the amount of boron in the soil affects the factors such as the type of plant, the amount of organic ions, the temperature of the soil, as well as the variety of the plant and the $\mathrm{pH}$ of the soil (Şimşek et al. 2003).

Boron deficiency is not as little as it is seen in more than 80 countries around the world (Shorrocks 1977). Lehto et al. (2010); Bell and Dell (2008), according to the area of the precipitation of sandy soils and alkaline $\mathrm{pH}$ soil is very common in the lack of boron. In addition to this, the lack of good soil management and fertilization is the inevitable result when the deficiency of plant nutrient elements in 
the soil increases with the advancement of agricultural activities. On the other hand, boron toxicity is a serious problem in arid regions where predominantly trees are not dominated in many parts of the world, and the window between deficiency and toxicity is generally known to be very narrow (Lehto et al. 2010). In other words, while the boron, which is found in very low amounts in some soils, has a deficiency for plants as a nutrient, it can be reached to toxic level for the plants by giving too much. Boron element in the production of pectic cells in the cell wall in plant production has been suggested to play an important role (Lehto et al. 2010), although many studies on the effect in the plant in general, the plant functions are not understood clearly (Demirtaş 2005).

Yalçın and Çimrin (2017) aimed to determine boron content of meadow and pasture soils in KırıhanReyhanl1 region of Hatay province and to determine their relationships with some properties of soil. According to the results of their work; $\mathrm{pH}$ contents of soils 6.85-8.16; salt content $0.01-0.21 \%$; clay contents 4.60-65.30\%; sand contents\% 8.70-85.40; silt contents $8.00-58.00 \%$; lime content 3.40$53.95 \%$; organic matter contents were found between $0.29-5.52 \%$ and the contents of boron were found between $0.00-1.31 \mathrm{ppm}$. At the same time, in terms of boron content of meadow pasture soils at a depth of $0-20 \mathrm{~cm} 70 \%$ very little, $27.50 \%$ less, $2.50 \%$ sufficient level, $20-40 \mathrm{~cm}$ depth $72.50 \%$ very little, $17.50 \%$ They found that less than $10 \%$ of them have sufficient levels. In addition, the negative relationship between the boron and sand contents of the soil is determined while the important relationship between the contents of salt, clay, silt and lime content of the boron. Özyazıc1 et al. (2013) aimed to reveal the physical and chemical properties of the alfalfa cultivated soil and the problems related to plant nutrition in Artvin region. According to the results of the study; the soil is generally of clayey loam, sand, sandy loam and sandy loam, $55.13 \%$ of them have neutral reactions, $58.97 \%$ of them have low calciferous and no salinity problems. In addition, it was determined that $46.16 \%$ of the soil has the deficiency of extractable boron and $16.67 \%$ of the soil has the deficiency of the extractable Mn. Taban et al. (2004), who determined the fertility status and nutritional problems of the soil made of garlic cultivation in the Kastamonu Taşköprü region, found within the results of their study that the soil in the region has no issues of salinity; in $85.00 \%$ of the soils KDK had $>25 \mathrm{mg} / \mathrm{kg}$ soil, and in $55.00 \%$ of the soils organic matter was insufficient, in $45.00 \%$ of the medium and $67.50 \%$ of it was insufficient in terms of boron. Budak and Günal (2015) aimed to map the distance-dependent variation of the available boron concentration in the salt and alkaline soils in the Bor district of Niğde province by geostatistical methods. As a result of the study, the boron concentration of the soil varied between 1.41 and $97.84 \mathrm{mg} / \mathrm{kg}$ and the average concentration was $47.76 \mathrm{mg} / \mathrm{kg}$. They found that in a large part of the study area soils the boron concentration is over $5 \mathrm{mg} / \mathrm{kg}$, which is the toxic limit for most crops.

In this study, the sludge contents of wide soil groups in Siverek district of Şanliurfa province will be investigated and their relations with some soil properties will be investigated. As a result, it was aimed to contribute to the yield and quality of agricultural production in wide soil groups in Siverek district.

\section{MATERIAL AND METHOD}

A total of 76 soil samples from 38 points, $0-20$ and 20-40 cm depths were taken in a manner to represent the region in the area of Siverek county of Şanlıurfa province in accordance with the procedure (Figure 1; Table 1). The soil samples brought to the laboratory on the same day were dried in the shade and dried by a $2 \mathrm{~mm}$ sieve. 


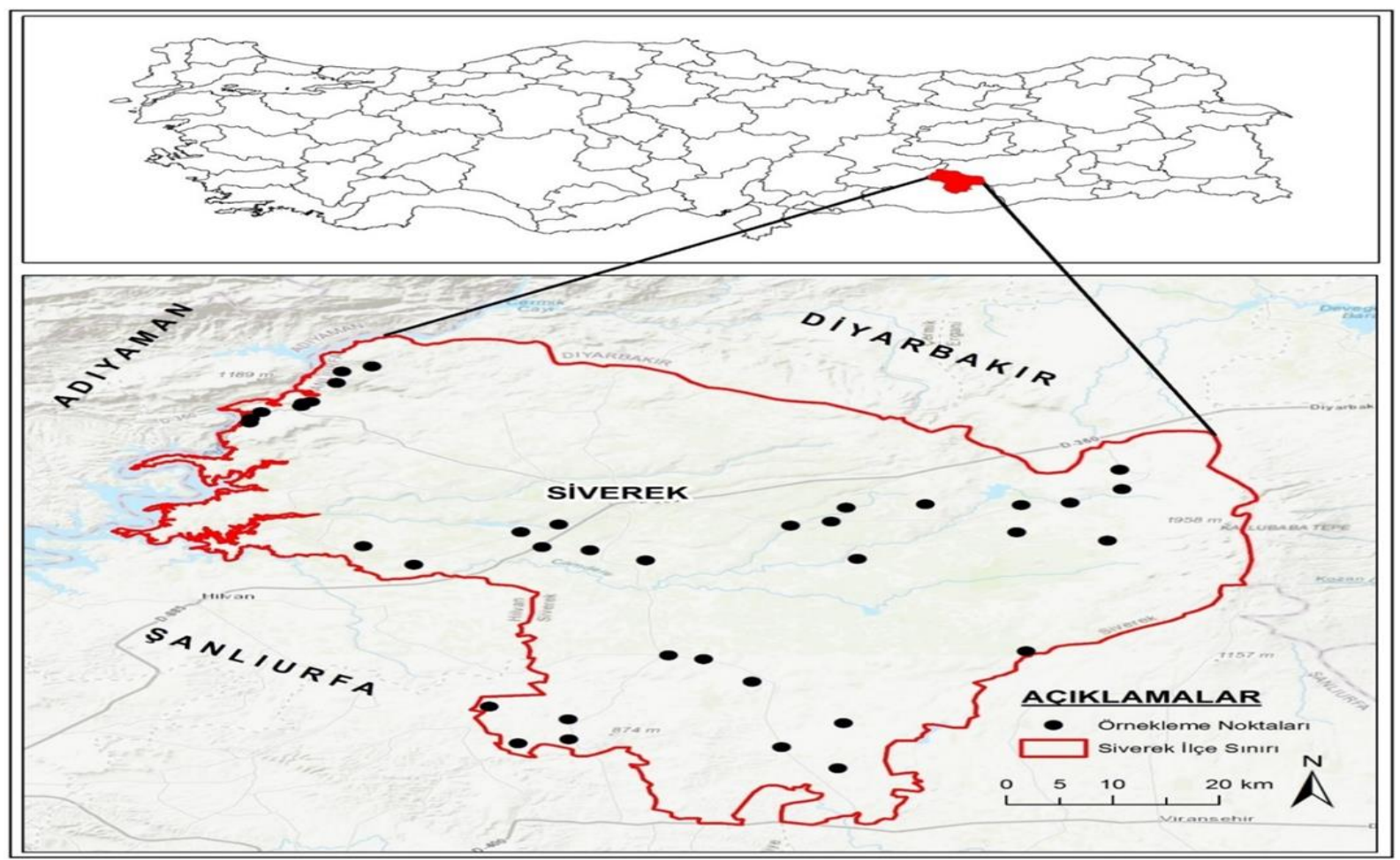

Figure 1. Representation of soil samples taken on Siverek district map.

Table 1. Soil samples were taken

\begin{tabular}{cccccc}
$\begin{array}{c}\text { Soil } \\
\text { Number }\end{array}$ & Sample Place & $\begin{array}{c}\text { Soil Class (IUSS } \\
\text { WRB Working } \\
\text { Group 2015) }\end{array}$ & $\begin{array}{c}\text { Soil } \\
\text { Number }\end{array}$ & Sample Place & $\begin{array}{c}\text { Soil Class (IUSS } \\
\text { WRB Working } \\
\text { Group 2015) }\end{array}$ \\
\hline 1 & Gözelek & Cambisol & 20 & Aşağıkarabahçe & Vertisol \\
2 & Karakoyun & Cambisol & 21 & Sabanl-1 & Cambisol \\
3 & Çeltik & Cambisol & 22 & Karakeçi & Cambisol \\
4 & Çanakçı & Cambisol & 23 & Turna & Cambisol \\
5 & Yücelen-1 & Cambisol & 24 & Başbuk-1 & Calcisol \\
6 & Yücelen-2 & Cambisol & 25 & Başbuk-2 & Calcisol \\
7 & Ediz & Cambisol & 26 & Alayurt & Cambisol \\
8 & Çatlı & Cambisol & 27 & Aşağlkaracaören & Cambisol \\
9 & Erkonağ1 & Cambisol & 28 & Karadibek & Cambisol \\
10 & Gedik & Cambisol & 29 & Sabanl1-2 & Vertisol \\
11 & Gazi & Cambisol & 30 & Ergen-1 & Cambisol \\
12 & Eğriçay & Cambisol & 31 & Narlıkaya-1 & Cambisol \\
13 & Savucak & Vertisol & 32 & Narlıkaya-2 & Cambisol \\
14 & Karacadağ-1 & Vertisol & 33 & Narlıkaya-3 & Cambisol \\
15 & Sumaklı & Vertisol & 34 & Ergen-2 & Cambisol \\
16 & Keçikıran & Cambisol & 35 & Ergen-3 & Cambisol \\
17 & Karacadağ-2 & Cambisol & 36 & Kayal1-1 & Cambisol \\
18 & Altınahır & Cambisol & 37 & Kayal1-2 & Cambisol \\
19 & Altınlı & Cambisol & 38 & Kayal1-3 & Cambisol \\
\hline
\end{tabular}

\section{Methods}

The total soluble salt content of the soils was measured in the electrical conductivity instrument in the saturation sludge extract and the $\mathrm{pH}$ values in the $\mathrm{pH}$ meter instrument (Richards 1954). Lime $\left(\mathrm{CaCO}_{3}\right)$ contents were measured with Scheibler calcimetres (Allison and Moode 1965). It was determined by 
hydrometer method (Bouyoucos 1952). The organic matter contents of soils were determined by the Walkley-Black method modified by Jackson (1960). Available B analysis of the soils was determined using ICP-OES device in strainer obtained using $0.01 \mathrm{M}$ mannitol $+0.01 \mathrm{M} \mathrm{CaCl}_{2}$ extract solution (Cartwright et al. 1983). Correlation and regression analysis of soil properties and available boron contents were done by SPSS 17 statistical program (Düzgüneş et al. 1987).

\section{RESULTS AND DISCUSSION}

\section{Some Physical and Chemical Properties of Soils}

Some physical and chemical properties of soil properties used in the research are given in Table 2. The $\mathrm{pH}$ content of the study soils was 6.91 in the samples and the highest $\mathrm{pH}$ content was 7.98 . The average $\mathrm{pH}$ content of the soil samples of 0-20 cm depth was 7.54, whereas the samples with a depth of 20-40 $\mathrm{cm}$ were 7.57 and it was 7.55 in two depths. According to Ülgen and Yurtsever (1995), the pH of the soil samples ranged from neutral to slightly alkaline, whereas $42.10 \%$ of the soils were neutral and $57.90 \%$ were slightly alkaline (Table 2). Saraçoğlu et al. (2014), who work in the same land, reported similar results in the study of some of the soil and plant nutrient contents of the territory of Halfeti district of Şanlıurfa province.

The salt content of the soil in the study area was $0.02 \%$, the highest salt content was $0.13 \%$. The average of 0 to $20 \mathrm{~cm}$ of soil samples was $0.06 \%$, while the samples with a depth of $20-40 \mathrm{~cm}$ were $0.07 \%$ and the mean of both depths was $0.07 \%$. According to the limit values reported by Richards 1954 , the total salt content of the soil samples was determined as salt-free (Table 2). In the same region, the general nutrition status of some olive orchards located in the center and districts of Şanliurfa was investigated by Söylemez et al. (2017) who also reported that all of the \% salt contents of soils were in the salt-free class.

The clay, sand and silt quantities of the soil of the major soil groups in Siverek district were at least $24.32 \%, 2.40 \%$ and $6.00 \%$ respectively, while the highest clay, sand and silt contents were $67.76 \%$, $62.96 \%$ and $68.72 \%$, respectively. The average clay, sand and silt contents of the soils at $0-20 \mathrm{~cm}$ depth were $34.61 \%, 21.08 \%$ and $44.31 \%$, while the mean values were $33.68 \%, 23.07 \%$ and $43.25 \%$ for samples with a depth of $20-40 \mathrm{~cm}$, and $34.15 \%, 22.08 \%$ and $43.78 \%$, respectively. The land of Siverek district As seen in Table 2, $51.32 \%$ of silty clay, $10.53 \%$ clay, $10.53 \%$ clayey loam, $2.63 \%$ loamy $5.26 \%$ sandy clay, $9.22 \%$ silty loam, $3.94 \%$ of the silty clay and $6.75 \%$ of the sandy clay was entered into 8 different class of textures. Saraçoğlu et al. (2014), who work in the same land, reported similar results in the study of some of the soil and plant nutrient contents of the land of Şanlıurfa- Halfeti province.

\section{Texture, pH, salt, lime, organic matter}

The lime content of the research lands was $0.38 \%$ in the samples while the highest lime content was determined as $14.55 \%$. The average lime content of the $0-20 \mathrm{~cm}$ depth samples was $3.64 \%$ in the depths of $20-40 \mathrm{~cm}$ and $3.87 \%$ in the depths of the soil. According to the classification of soil samples by Ülgen and Yurtsever (1995), although the contents of the lime ranged between low calcareous and medium calcareous, $2.64 \%$ of the soils were found to be low calcareous, $73.68 \%$ were calcareous and $23.68 \%$ were medium calcareous (Table 2). Saraçoğlu et al. (2014) The lime content of the soils of Halfeti district of Şanlıurfa province has changed between $0.38 \%$ and $33.80 \%, 4.00 \%$ of the soils are less calcareous, $48.00 \%$ is calcareous, $17.00 \%$ is medium, $9.00 \%$ is more than $22.00 \%$. reported that they were too calcareous. 
Table 2. Some physical and chemical properties and boron contents of wide soil groups in ŞanlıurfaSiverek Province.

\begin{tabular}{|c|c|c|c|c|c|c|c|c|c|c|}
\hline $\begin{array}{c}\text { Soil } \\
\text { Number }\end{array}$ & Depth & $\mathrm{pH}$ & $\begin{array}{c}\text { Salt } \\
\%\end{array}$ & $\begin{array}{c}\text { Clay } \\
\%\end{array}$ & $\begin{array}{c}\text { Sand } \\
\%\end{array}$ & $\begin{array}{c}\text { Silt } \\
\%\end{array}$ & $\begin{array}{c}\text { Texture } \\
\text { class }\end{array}$ & $\underset{\%}{\operatorname{Lime}}$ & $\begin{array}{c}\text { O.M. } \\
\%\end{array}$ & $\begin{array}{c}\mathrm{B} \\
\mathrm{mg} / \mathrm{kg}\end{array}$ \\
\hline \multirow[t]{2}{*}{1} & $0-20$ & 7.28 & 0.04 & 24.32 & 21.68 & 54.00 & SiL & 1.47 & 1.90 & 0.06 \\
\hline & $20-40$ & 7.29 & 0.05 & 26.32 & 23.68 & 50.00 & $\mathrm{SiL}$ & 1.47 & 1.88 & 0.24 \\
\hline \multirow[t]{2}{*}{2} & $0-20$ & 7.67 & 0.08 & 35.04 & 9.68 & 55.28 & SiCL & 2.71 & 1.95 & 0.15 \\
\hline & $20-40$ & 7.74 & 0.08 & 31.76 & 15.68 & 52.56 & $\mathrm{SiCL}$ & 2.69 & 1.66 & 0.29 \\
\hline \multirow[t]{2}{*}{3} & $0-20$ & 7.74 & 0.06 & 30.32 & 13.68 & 56.00 & $\mathrm{SiCL}$ & 1.31 & 1.53 & 0.63 \\
\hline & $20-40$ & 7.79 & 0.07 & 30.32 & 14.96 & 54.72 & $\mathrm{SiCL}$ & 1.54 & 1.55 & 0.23 \\
\hline \multirow[t]{2}{*}{4} & $0-20$ & 7.39 & 0.10 & 32.32 & 11.68 & 56.00 & SiCL & 1.31 & 2.11 & 0.39 \\
\hline & $20-40$ & 7.42 & 0.10 & 32.32 & 14.96 & 52.72 & SiCL & 1.69 & 1.99 & 0.39 \\
\hline \multirow[t]{2}{*}{5} & $0-20$ & 7.44 & 0.10 & 34.32 & 7.68 & 58.00 & SiCL & 1.46 & 1.90 & 0.06 \\
\hline & $20-40$ & 7.40 & 0.10 & 32.32 & 10.96 & 56.72 & SiCL & 1.46 & 1.66 & 0.46 \\
\hline \multirow[t]{2}{*}{6} & $0-20$ & 7.65 & 0.08 & 27.04 & 19.68 & 53.28 & SiCL & 3.16 & 2.27 & 0.07 \\
\hline & $20-40$ & 7.58 & 0.10 & 30.32 & 17.68 & 52.00 & $\mathrm{SiCL}$ & 1.54 & 2.05 & 0.28 \\
\hline \multirow[t]{2}{*}{7} & $0-20$ & 7.74 & 0.08 & 30.32 & 13.68 & 56.00 & $\mathrm{SiCL}$ & 1.54 & 1.85 & 0.02 \\
\hline & $20-40$ & 7.80 & 0.08 & 31.04 & 20.40 & 48.56 & CL & 1.92 & 1.49 & 0.13 \\
\hline \multirow[t]{2}{*}{8} & $0-20$ & 7.57 & 0.08 & 32.32 & 22.96 & 44.72 & CL & 4.39 & 3.33 & 0.01 \\
\hline & $20-40$ & 7.55 & 0.08 & 32.32 & 12.40 & 55.28 & SiCL & 2.69 & 3.26 & 0.18 \\
\hline \multirow[t]{2}{*}{9} & $0-20$ & 7.88 & 0.05 & 26.32 & 20.40 & 53.28 & SiL & 10.47 & 1.64 & 0.11 \\
\hline & $20-40$ & 7.85 & 0.05 & 30.32 & 22.96 & 46.72 & $\mathrm{CL}$ & 10.16 & 1.60 & 0.81 \\
\hline \multirow[t]{2}{*}{10} & $0-20$ & 7.48 & 0.09 & 34.32 & 12.40 & 53.28 & SiCL & 0.38 & 1.80 & 0.04 \\
\hline & $20-40$ & 7.52 & 0.10 & 32.32 & 12.96 & 54.72 & SiCL & 1.46 & 1.55 & 0.18 \\
\hline \multirow[t]{2}{*}{11} & $0-20$ & 7.41 & 0.07 & 36.32 & 8.40 & 55.28 & SiCL & 1.15 & 1.58 & 0.65 \\
\hline & $20-40$ & 7.48 & 0.07 & 40.32 & 8.96 & 50.72 & $\mathrm{SiC}$ & 1.31 & 1.38 & 0.10 \\
\hline \multirow[t]{2}{*}{12} & $0-20$ & 7.36 & 0.06 & 30.32 & 12.40 & 57.28 & SiCL & 1.15 & 2.51 & 0.01 \\
\hline & $20-40$ & 7.41 & 0.07 & 34.32 & 12.96 & 52.72 & $\mathrm{SiCL}$ & 1.15 & 2.41 & 0.12 \\
\hline \multirow[t]{2}{*}{13} & $0-20$ & 7.11 & 0.06 & 67.76 & 2.40 & 29.84 & $\mathrm{C}$ & 1.08 & 1.85 & 0.52 \\
\hline & $20-40$ & 7.07 & 0.06 & 46.32 & 8.96 & 44.72 & $\mathrm{SiC}$ & 1.31 & 1.83 & 0.25 \\
\hline \multirow[t]{2}{*}{14} & $0-20$ & 7.06 & 0.06 & 65.76 & 8.40 & 25.84 & $\mathrm{C}$ & 1.15 & 2.17 & 0.08 \\
\hline & $20-40$ & 7.10 & 0.06 & 64.32 & 11.68 & 24.00 & $\mathrm{C}$ & 1.23 & 1.88 & 0.18 \\
\hline \multirow[t]{2}{*}{15} & $0-20$ & 7.27 & 0.07 & 52.32 & 14.40 & 33.28 & $\mathrm{C}$ & 1.00 & 1.58 & 0.41 \\
\hline & $20-40$ & 7.36 & 0.07 & 42.32 & 14.40 & 43.28 & $\mathrm{SiC}$ & 1.39 & 1.49 & 0.06 \\
\hline \multirow[t]{2}{*}{16} & $0-20$ & 7.67 & 0.08 & 30.32 & 12.40 & 57.28 & SiCL & 3.52 & 1.27 & 0.03 \\
\hline & $20-40$ & 7.73 & 0.08 & 32.32 & 15.68 & 52.00 & $\mathrm{SiCL}$ & 4.52 & 1.11 & 0.81 \\
\hline \multirow[t]{2}{*}{17} & $0-20$ & 7.73 & 0.07 & 30.32 & 16.40 & 53.28 & SiCL & 2.37 & 1.98 & 0.12 \\
\hline & $20-40$ & 7.75 & 0.07 & 26.32 & 21.68 & 52.00 & SiL & 2.68 & 1.69 & 0.27 \\
\hline \multirow[t]{2}{*}{18} & $0-20$ & 7.78 & 0.06 & 34.32 & 8.40 & 57.28 & SiCL & 3.16 & 1.98 & 0.06 \\
\hline & $20-40$ & 7.82 & 0.07 & 28.32 & 13.68 & 58.00 & $\mathrm{SiCL}$ & 3.69 & 1.88 & 0.16 \\
\hline \multirow[t]{2}{*}{19} & $0-20$ & 7.75 & 0.07 & 31.04 & 14.40 & 54.56 & $\mathrm{SiCL}$ & 1.46 & 1.53 & 0.89 \\
\hline & $20-40$ & 7.71 & 0.07 & 30.32 & 17.68 & 52.00 & $\mathrm{SiCL}$ & 1.77 & 2.10 & 0.11 \\
\hline \multirow[t]{2}{*}{20} & $0-20$ & 6.98 & 0.04 & 48.32 & 18.40 & 33.28 & $\mathrm{C}$ & 8.74 & 2.17 & 0.01 \\
\hline & $20-40$ & 6.91 & 0.04 & 44.32 & 15.68 & 40.00 & $\mathrm{C}$ & 9.39 & 2.16 & 0.36 \\
\hline
\end{tabular}


Table 2. (continued)

\begin{tabular}{|c|c|c|c|c|c|c|c|c|c|c|}
\hline $\begin{array}{c}\text { Soil } \\
\text { Number }\end{array}$ & Depth & $\mathrm{pH}$ & $\begin{array}{l}\text { Salt } \\
\%\end{array}$ & $\begin{array}{c}\text { Clay } \\
\%\end{array}$ & $\begin{array}{c}\text { Sand } \\
\%\end{array}$ & $\begin{array}{l}\text { Silt } \\
\%\end{array}$ & $\begin{array}{c}\text { Texture } \\
\text { class }\end{array}$ & $\begin{array}{c}\text { Lime } \\
\%\end{array}$ & $\begin{array}{c}\text { O.M. } \\
\%\end{array}$ & $\begin{array}{c}\mathrm{B} \\
\mathrm{mg} / \mathrm{kg}\end{array}$ \\
\hline \multirow[t]{2}{*}{21} & $0-20$ & 7.82 & 0.06 & 30.32 & 16.40 & 53.28 & SiCL & 6.23 & 2.01 & 1.08 \\
\hline & $20-40$ & 7.85 & 0.06 & 30.32 & 15.68 & 54.00 & SiCL & 6.16 & 1.74 & 0.95 \\
\hline \multirow[t]{2}{*}{22} & $0-20$ & 7.37 & 0.09 & 24.32 & 22.40 & 53.28 & SiL & 4.23 & 2.48 & 0.06 \\
\hline & $20-40$ & 7.39 & 0.08 & 30.32 & 19.68 & 50.00 & SiCL & 4.62 & 2.43 & 0.17 \\
\hline \multirow[t]{2}{*}{23} & $0-20$ & 7.51 & 0.10 & 28.32 & 16.40 & 55.28 & SiCL & 2.31 & 2.01 & 0.43 \\
\hline & $20-40$ & 7.54 & 0.12 & 32.32 & 13.68 & 54.00 & SiCL & 1.62 & 2.02 & 0.32 \\
\hline \multirow[t]{2}{*}{24} & $0-20$ & 7.65 & 0.08 & 30.32 & 14.40 & 55.28 & SiCL & 13.86 & 2.43 & 0.13 \\
\hline & $20-40$ & 7.71 & 0.08 & 28.32 & 14.96 & 56.72 & SiCL & 14.55 & 2.38 & 0.23 \\
\hline \multirow[t]{2}{*}{25} & $0-20$ & 7.76 & 0.04 & 36.32 & 12.96 & 50.72 & SiCL & 7.77 & 2.56 & 0.10 \\
\hline & $20-40$ & 7.79 & 0.04 & 36.32 & 13.68 & 50.00 & SiCL & 8.47 & 2.35 & 0.15 \\
\hline \multirow[t]{2}{*}{26} & $0-20$ & 7.81 & 0.05 & 28.32 & 2.96 & 68.72 & $\mathrm{SiCL}$ & 1.92 & 1.74 & 0.23 \\
\hline & $20-40$ & 7.88 & 0.04 & 23.60 & 10.96 & 65.44 & SiL & 2.69 & 1.77 & 0.10 \\
\hline \multirow[t]{2}{*}{27} & $0-20$ & 7.77 & 0.06 & 28.32 & 13.68 & 58.00 & SiCL & 2.31 & 1.93 & 1.99 \\
\hline & $20-40$ & 7.74 & 0.06 & 30.32 & 14.96 & 54.72 & $\mathrm{SiCL}$ & 2.69 & 1.94 & 0.96 \\
\hline \multirow[t]{2}{*}{28} & $0-20$ & 7.76 & 0.05 & 30.32 & 17.68 & 52.00 & SiCL & 8.31 & 2.38 & 1.13 \\
\hline & $20-40$ & 7.82 & 0.06 & 28.32 & 22.96 & 48.72 & $\mathrm{SiCL}$ & 8.39 & 2.43 & 0.23 \\
\hline \multirow[t]{2}{*}{29} & $0-20$ & 7.49 & 0.12 & 46.32 & 21.68 & 32.00 & $\mathrm{C}$ & 3.46 & 3.35 & 0.15 \\
\hline & $20-40$ & 7.57 & 0.13 & 50.32 & 14.96 & 34.72 & $\mathrm{C}$ & 4.16 & 3.15 & 0.21 \\
\hline \multirow[t]{2}{*}{30} & $0-20$ & 7.30 & 0.05 & 26.32 & 11.68 & 62.00 & $\mathrm{SiL}$ & 1.08 & 2.54 & 0.01 \\
\hline & $20-40$ & 7.39 & 0.05 & 27.76 & 30.96 & 41.28 & SiCL & 1.54 & 2.21 & 0.01 \\
\hline \multirow[t]{2}{*}{31} & $0-20$ & 7.06 & 0.02 & 34.32 & 55.68 & 10.00 & SCL & 1.15 & 1.56 & 0.01 \\
\hline & $20-40$ & 7.09 & 0.02 & 34.32 & 54.24 & 11.44 & SCL & 0.85 & 1.44 & 0.04 \\
\hline \multirow[t]{2}{*}{32} & $0-20$ & 7.22 & 0.02 & 37.04 & 47.68 & 15.28 & $\mathrm{SC}$ & 1.15 & 1.37 & 0.21 \\
\hline & $20-40$ & 7.31 & 0.02 & 37.04 & 48.24 & 14.72 & $\mathrm{SC}$ & 1.62 & 1.16 & 0.09 \\
\hline \multirow[t]{2}{*}{33} & $0-20$ & 7.94 & 0.03 & 26.32 & 31.68 & 42.00 & $\mathrm{~L}$ & 8.47 & 1.53 & 0.75 \\
\hline & $20-40$ & 7.98 & 0.03 & 28.32 & 42.24 & 29.44 & CL & 8.47 & 1.58 & 0.93 \\
\hline \multirow[t]{2}{*}{34} & $0-20$ & 7.97 & 0.04 & 32.32 & 42.96 & 24.72 & CL & 7.54 & 1.43 & 0.64 \\
\hline & $20-40$ & 7.95 & 0.04 & 26.32 & 44.96 & 28.72 & $\mathrm{~L}$ & 8.01 & 1.27 & 0.30 \\
\hline \multirow[t]{2}{*}{35} & $0-20$ & 7.78 & 0.04 & 37.76 & 37.68 & 24.56 & $\mathrm{CL}$ & 11.55 & 2.98 & 0.79 \\
\hline & $20-40$ & 7.86 & 0.04 & 36.32 & 36.24 & 27.44 & CL & 12.55 & 3.10 & 1.82 \\
\hline \multirow[t]{2}{*}{36} & $0-20$ & 7.32 & 0.02 & 38.32 & 45.68 & 16.00 & $\mathrm{CL}$ & 1.00 & 1.21 & 0.49 \\
\hline & $20-40$ & 7.41 & 0.02 & 32.32 & 54.96 & 12.72 & SCL & 1.31 & 1.13 & 0.14 \\
\hline \multirow[t]{2}{*}{37} & $0-20$ & 7.47 & 0.02 & 30.32 & 62.24 & 7.44 & SCL & 1.54 & 1.48 & 0.33 \\
\hline & $20-40$ & 7.52 & 0.02 & 28.32 & 62.96 & 8.72 & SCL & 1.54 & 1.38 & 0.03 \\
\hline \multirow[t]{2}{*}{38} & $0-20$ & 7.43 & 0.03 & 36.32 & 57.68 & 6.00 & $\mathrm{SC}$ & 1.54 & 1.74 & 0.22 \\
\hline & $20-40$ & 7.46 & 0.03 & 40.32 & 52.24 & 7.44 & $\mathrm{SC}$ & 1.54 & 1.60 & 0.06 \\
\hline \multicolumn{2}{|l|}{ Min } & 6.91 & 0.02 & 24.32 & 2.40 & 6.00 & & 0.38 & 1.11 & 0.01 \\
\hline \multicolumn{2}{|l|}{ Max } & 7.98 & 0.13 & 67.76 & 62.96 & 68.72 & & 14.55 & 3.35 & 1.99 \\
\hline \multirow{3}{*}{$\begin{array}{l}\text { Ave. } \\
\text { Ave. }\end{array}$} & $0-20$ & 7.54 & 0.06 & 34.61 & 21.08 & 44.31 & & 3.64 & 1.99 & 0.34 \\
\hline & $20-40$ & 7.57 & 0.07 & 33.68 & 23.07 & 43.25 & & 3.84 & 1.89 & 0.33 \\
\hline & Ave. & 7.55 & 0.07 & 34.15 & 22.08 & 43.78 & & 3.74 & 1.94 & 0.34 \\
\hline
\end{tabular}

The organic matter content of the soils was $1.11 \%$ and the highest organic matter was $3.35 \%$. The average organic matter of the samples in the $0-20 \mathrm{~cm}$ depth of soil was $1.99 \%$ and $1.89 \%$ in the samples with a depth of $20-40 \mathrm{~cm}$ and $1.94 \%$ in two depths. According to Ülgen and Yurtsever (1995) classification of soil samples, although organic matter varied between very low and medium level, $63.16 \%$ of the soils were less, $30.26 \%$ were medium and $6.58 \%$ were good organic matter (Table 2). The aim of the study was to determine the general nutritional status of some olive orchards in the center 
and districts of Şanliurfa in the same region. Söylemez et al. (2017) The organic matter contents of the lands of Şanliurfa have been reported to be between $0.37 \%$ and $2.32 \%$ and, $88.24 \%$ of the soils have low organic matter content.

The lowest boron concentration was $0.01 \mathrm{mg} / \mathrm{kg}$ and the highest boron concentration was $1.99 \mathrm{mg} / \mathrm{kg}$. The contents of the samples taken from $0-20 \mathrm{~cm}$ depth of soil were $0.34 \mathrm{mg} / \mathrm{kg}$ and the soil samples of $20-40 \mathrm{~cm}$ depth were $0.33 \mathrm{mg} / \mathrm{kg}$ and $0.34 \mathrm{mg} / \mathrm{kg}$. Wolf (1971) in terms of boron boundary values in the soil compared to the province of Şanlıurfa Siverek district in terms of boron content of wide soil groups at a depth of $0-20 \mathrm{~cm} 65.78 \%$ very little $(<0.4 \mathrm{mg} / \mathrm{kg}), 26.32 \%$ less $(0.5-0.9 \mathrm{mg} / \mathrm{kg}, 7.90 \%$ was sufficient (1.0-2.4), at $20-40 \mathrm{~cm}$ depth, $81.58 \%$ was found to be very small, $15.79 \%$ was low and $2.63 \%$ was sufficient (Table 2). The aim of the study was to determine the general nutritional status of some olive orchards in the center and districts of Şanlıurfa in the same region Söylemez et al. (2017) reported similar results.

\section{Relationship Between Boron Content and Some Other Soil Properties}

The relationship between some physical and chemical properties of soil properties and boron contents can be found in Table 3. As can be seen from the analysis of the table, the $\mathrm{pH}$ content (r: $0.39 * * *$; Fig. 2) and the lime content (r: $0.32 * * *$; Fig. 3 ) have positive correlations with boron. In addition, the negative content ( $\mathrm{r}:-0.56 * * *)$ relationship between the $\mathrm{pH}$ content of the soil and the clay content, whereas a highly positive ones were determined between the content of the silt ( $\mathrm{r}: 0.37 * * *)$ and lime ( $\mathrm{r}: 0.43^{* * *}$ ). It has been identified that there is the negative ( $\left.\mathrm{r}:-0.66 * * *\right)$ relationships between the salt content of the soils and the sand contents, while the salt content of the soils and the silt (r: $0.59 * * *)$ and the organic matter (r: $0.37 * * *$ ) were significantly positive. Parlak et al. (2008) in the study which aims to determine the productivity status of the agricultural lands of the Eceabat district of Çanakkale, found similar results between the salt content of the soils and the sand, silt and organic matter content characteristics. In a study conducted in a different region, chemical fractions of the region of Tokat Kazovas1 and another study in which the relationships between these fractions and soil properties were determined, similar results were reported between the salt, sand and salt and silt and organic matter properties of the soils (Saltalı and Akın 2010). Negative significant (r: $-0.40 * * *)$ relationship was determined between clay content and silt content of soils. Soba et al. (2015) Ankara University Faculty of Agriculture Haymana research and application farm in the study of the productivity status of the soil clay and silt content of the soil properties have obtained similar results. The sand content of silt ( $\mathrm{r}:-0.85$ $* * *)$ and organic matter (r: $-0.29 *$ ) were determined as negative significant relationships between them. Significant relationships were determined between the lime content of the soils ( $\mathrm{r}: 0.52 * * *)$ and the organic matter (r: $0.32 * * *)$.

Table 3. Correlation coefficients of the wide soil groups of Siverek district of Şanlıurfa province between boron and some soil properties.

\begin{tabular}{llllllll}
\hline & $\begin{array}{c}\mathrm{B} \\
\mathrm{mg} / \mathrm{kg}\end{array}$ & $\mathrm{pH}$ & $\begin{array}{l}\text { Salt } \\
(\%)\end{array}$ & $\begin{array}{l}\text { Clay } \\
(\%)\end{array}$ & $\begin{array}{c}\text { Sand } \\
(\%)\end{array}$ & $\begin{array}{c}\text { Silt } \\
(\%)\end{array}$ & $\begin{array}{c}\text { Lime } \\
(\%)\end{array}$ \\
\hline $\mathrm{pH}$ & $0.39 * * *$ & & & & & & \\
Salt $(\%)$ & -0.09 & 0.08 & & & & \\
Clay $(\%)$ & -0.07 & $-0.56 * * *$ & 0.04 & & & \\
Sand $(\%)$ & -0.01 & -0.07 & $-0.66^{* * *}$ & -0.15 & & \\
Silt $(\%)$ & 0.04 & $0.37 * * *$ & $0.59 * * *$ & $-0.40 * * *$ & $-0.85 * * *$ & \\
Lime $(\%)$ & $0.32 * * *$ & $0.43 * * *$ & -0.14 & -0.14 & 0.04 & 0.04 & \\
OM $(\%)$ & 0.01 & 0.01 & $0.37 * * *$ & 0.10 & $-0.29 *$ & 0.22 & $0.32 * * *$ \\
\hline
\end{tabular}

* significant at 0.05 level, *** significant at 0.001 level 


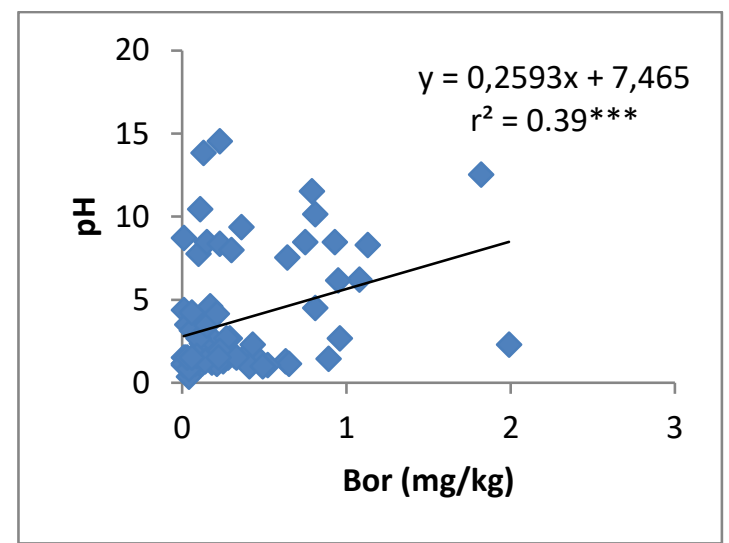

Figure 2. The relationship between the soil content of available boron and $\mathrm{pH}$ content

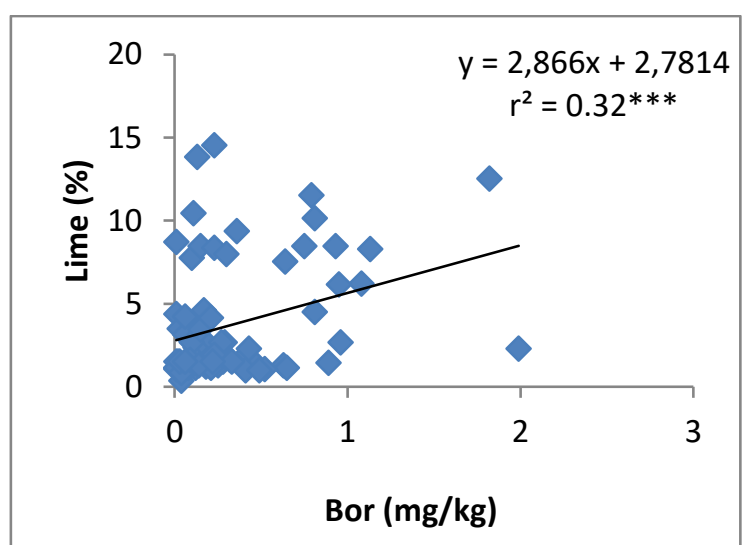

Figure 3. The relationship between the soil content of available boron and Lime content

\section{CONCLUSION}

It was tried to determine the wide soil groups in the Siverek district of Şanlıurfa province, the available boron state and its relationship with some soil properties. As a result, the soil of the wide soil groups in the province of Siverek in terms of soil reaction in general is suitable for planting with a slightly alkaline; as having a salt-free class they show a lack of any problems when considered in terms of salinity. It is determined that the soil of the wide soil groups of Siverek district of Şanliurfa province has 8 different texture classes and $72.41 \%$ of the total amount of clayey soils, silty clayey clay and clay containing soils are found in the lands. It has been determined that the investigated soil has calcareous and medium calcareous environments in terms of lime and it has been observed that it has low and medium amount of organic content in terms of organic matter. In terms of the available boron of the studied Siverek district, it was determined that the amount of available boron contents of the soil $(0-20$ and $20-40 \mathrm{~cm})$ at both depths $(0-20$ and $20-40 \mathrm{~cm})$ was insufficient with very low and low. Boron fertilization should be done in order to increase the yield in this land.

\section{REFERENCES}

Allison, L.E., Moode C.D. 1965. Carbonate. (ed: C.A. Black), Methods of soil analysis. Part 2. Agronomy Series. No. 9, ASA. 1379-1396, Wisconsin.

Bouyoucos, G.J. 1952. A Recalibration of the hydrometer for making mechanical analysis of soil. Agronomy Journal, 43 (9): 434-438.

Budak, M., Günal H. 2015. Tuzlu-Alkali topraklarda bor konsantrasyonunun uzaysal değişkenliğinin jeoistatistiksel analizi ve haritalanması. Ege Üniversitesi Ziraat Fakültesi Dergisi, 2015, 52(2): 191-200.

Cartwright, B., Tiller, K.G., Zarcinas, B.A., Spouncer, LR. 1983. The chemical assessment of the boron status of soils. Aust. J. Soil Res. 21:321-332.

Demirtaş, A. 2005. Bitkide bor ve etkileri. Atatürk Üniversitesi Ziraat Fakültesi Dergisi 36(2), 217-225.

Düzgüneş, O., Kesici, T., Kavuncu, O., Gürbüz, F. 1987. Araştırma deneme metotları (istatistik metotları-II). Ankara Üniversitesi Ziraat Fakültesi Yayınları:1021. Ankara, 381s.

Karaduman A., Çimrin K.M. 2016. Gaziantep Yöresi Tarım Topraklarının Besin Elementi Durumları ve Bunların Bazı Toprak Özellikleri ile İlişkileri. Kahramanmaraş Sütçü imam Üniversitesi Doğa Bilimleri Dergisi. 19(2): 117 129.

Lehto, T., Ruuholaa, T., Dellb, B. 2010. Boron in forest trees and forest ecosystems. Forest Ecology and Management, 260 2053-2069

Jackson, M.L. 1960. Soil chemical analysis, Prentice- Hall, Inc. Englewood,CliffsNJ.

Özyazıcı, M.A., Dengiz, O., Sağlam, M. 2013. Artvin ilinde yanca (medicago sativa L.) tarım yapılan toprakların verimlilik durumu ve potansiyel beslenme problemlerinin ortaya konulması. Artvin Çoruh Üniversitesi Orman Fakültesi Dergisi Cilt:14, sayı:2, sayfa: 225-238,

Parlak, M., Fidan, A., Kızılcık, İ., Koparan, H. 2008. Eceabat İlçesi (Çanakkale) Tarım Topraklarının Verimlilik Durumlarının Belirlenmesi. Tarım Bilimleri Dergisi 14(4): 394-400. 
Richards, L.A. 1954. Diagnosis and Improvement of Saline and Alkali Soils. USDA Handbook. 60 p. Saraçoğlu, M., Sürücü, A., Koşar, İ., Taş, M.A., Aydoğdu, M., Kara, H. 2014. Şanlıurfa ili Halfeti ilçesi topraklarının bazı özellikleri ve bitki besin elementi kapsamlarını belirlenmesi. Toprak Bilimi ve Bitki Besleme Dergisi 2 (2): 38-45.

Sevindik, M., Akgul, H., Pehlivan, M., Selamoglu, Z. 2017. Determination of therapeutic potential of Mentha longifolia ssp. longifolia. Fresen Environ Bull, 26: 4757-4763.

Shorrocks, V.M. 1997. The occurrence and correction of boron deficiency. Plant Soil 193, 121-148.

Soba, M., Türkmen, F., Taşkın, M.B., Akça, M.O., Öztürk, H.S. 2015. Ankara üniversitesi ziraat fakültesi haymana araştırma ve uygulama çiftliği topraklarının verimlilik durumlarını incelenmesi. Toprak Su Dergisi, 4 (1): 7-17.

Söylemez, S., Öktem, A.G., Kara, H., Almaca, N.D., Ak, B.E., Sakar, E. 2017. Şanlıurfa yöresi zeytinliklerinin beslenme durumunun belirlenmesi. Harran Tarım ve Gida Bilimleri Dergisi 21 (1): 1-15.

Saltalı, K., Akın, A. 2010. Tokat kazovası topraklarında borun kimyasal fraksiyonları ve bu fraksiyonlar ile toprak özellikleri arasındaki ilişkiler. 5. Ulusal Bitki Besleme ve Gübre Kongresi. 15-17 Eylül 2010 Ege Üniversitesi Ziraat Fakültesi, Bornova-İzmir, 379-385 s.

Şimşek, A., Velioğlu, S., Coşkun, A.İ., Şaylı, B.S. 2003. Boron concentrations of selected foods from borate production regions in Turkey. Journal Science Food Agriculture, vol:83(6), 586-592.

Taban, S., Çıkılı, Y., Kebeci, F., Taban, N., Sezer, S.M. 2004. Taşköprü yöresinde sarımsak tarımı yapılan toprakların verimlilik durumu ve potansiyel beslenme problemlerinin ortaya konulması. Tarım Bilimleri Dergisi 10(3) 297-304.

Ülgen, N., Yurtsever, N. 1995. Türkiye Gübre ve Gübreleme Rehberi (4. Baskı). T.C. Başbakanlık Köy Hizmetleri Genel Müdürlüğü Toprak ve Gübre Araştırma Enstitüsü Müdürlüğü Yayınları, Genel Yayın No: 209, Teknik Yayınlar No: T.66, Ankara.

Wolf, B. 1971. The determination of boron in soil extracts, plant materials, composts, manures, water and nutrient solutions. Soil Science and Plant Analysis, 2: 363-374.

Yalçın, M., Çimrin, K.M. 2017. Hatay ili Kırıkhan-Reyhanlı bölgesi çayır-mera topraklarının bor içeriğinin belirlenmesi ve toprağın bazı özelikleri ile ilişkilerinin belirlenmesi. Mesleki Bilimler Dergisi, 6(2): 201-210. 